\title{
Pengaruh Kualitas Laporan Keuangan Terhadap Akuntabilitas Kinerja Pada Kantor Pengadilan Agama Lubuklinggau
}

\author{
Kusnadi Yudha Wiguna ${ }^{1}$, Anggia Syafitri ${ }^{2}$, Ria Meika Putri ${ }^{3}$ \\ Universitas Musi Rawas \\ kusnadi.yudha@yahoo.co.id ${ }^{1}$, syafitrianggia82@,gmail.com², \\ riameikaputri@gmail.com ${ }^{3}$
}

\begin{abstract}
The aim of this study is to see the effect of financial report quality toward accountability performance in religious court of Lubuk Linggau. Variables of this study are financial report quality and toward accountability performance. Data of this study is qualitative and quantitative data through questionnaire shared to all religious court officers and financial report validated by Audit Board Republic of Indonesia . The result showed that the quality of financial report gave the significant effect on accountability performance in religious court of Lubuk Linggau by $t_{\text {count }}>t_{\text {table }}$, $(15,517>1,692)$, significant value with $0,000<0,05$ and determinant cooficient is 0,749 or 74,9 percent.
\end{abstract}

Kata Kunci: Laporan Keuangan, Akuntabilitas, Kinerja

\section{Pendahuluan}

Terciptanya kinerja yang baik disuatu instansi pemerintahan menjadi keinginan bersama keterbukaan di dalam pemerintahan menjadi tuntutan masyarakat dalam melaksanakan akuntabilitas publik oleh organisasi pemerintah, pemerintahan yang transparan dan akuntabel tentunya memiliki suatu jaminan bahwa segala informasi atau peristiwa penting dalam kegiatan pemerintah terekam dengan baik dengan suatu ukuran-ukuran yang jelas untuk mencapai tujuan tersebut pemerintah harus dapat mengelolah sumber daya yang ada di negara, salah satunya yang terpenting adalah keuangan sehingga keberhasilan yang akan dicapai oleh pemerintah dalam menjalankan tugasnya dalam membangun negaranya sesuai dengan tujuan yang telah direncanakan sesuai dengan standar akuntansi pemerintah untuk menciptakan good governance.

Penyusunan Laporan Keuangan Pengadilan Agama mengacu pada Peraturan Pemerintah Nomor 71 Tahun 2010 tentang Standar Akuntansi Pemerintahan dan kaidah-kaidah pengelolaan keuangan yang sehat dalam Pemerintahan, serta Peraturan Menteri Keuangan (PMK) Nomor 177/PMK.05/2015 tentang Pedoman Penyusunan Laporan Keuangan Kementerian Negara / Lembaga. Laporan keuangan ini telah disusun dan disajikan dengan basis akrual sehingga akan mampu menyajikan informasi keuangan yang transparan, akurat 
dan akuntabel. Peraturan Presiden Nomor 29 Tahun 2014 tentang sistem akuntabilitas kinerja instansi pemerintahan dan Menurut Surat Keputusan Kepala Lembaga Administrasi Negara Nomor 239/IX/6/8/2003 tanggal 25 Maret 2003 tentang pedoman penyusunan dan pelaporan akuntabilitas kinerja instansi pemerintah. Akuntabilitas terkait laporan keuangan tidak hanya mencakup penyajian laporan keuangan tetapi memuat hal berupa laporan yang mengandung informasi yang relevan dan memenuhi kebutuhan pengguna, melainkan juga laporan yang secara langsung tersedia dan dapat diakses oleh pihak-pihak yang menggunakan informasi tesebut. Untuk meningkatkan kualitas akuntabilitas laporan keuangan Kantor Pengadilan Agama maka laporan keuangannya harus diaudit oleh Badan Pemeriksa Keuangan.

Badan Pemeriksa Keuangan (BPK) telah mengaudit laporan keuangan Kantor Pengadilan Agama Lubuklinggau selama lima tahun 2015-2019. BPK telah memberikan opini Wajar Tanpa Pengecualian kepada Kantor Pengadilan Agama Lubuklinggau. Sebagaimana tersaji di dalam Tabel.1 berikut:

Tabel 1. Daftar Hasil Opini Kantor Pengadilan Agama Lubuklinggau (2015-2019)

\begin{tabular}{|l|c|c|c|c|c|}
\hline \multirow{2}{*}{ Nama Instansi } & \multicolumn{5}{|c|}{ Hasil Opini BPK } \\
\hline \multirow{2}{*}{$\begin{array}{l}\text { Pengadilan Agama } \\
\text { Lubuklinggau }\end{array}$} & 2015 & 2016 & 2017 & 2018 & 2019 \\
\cline { 2 - 6 } & WTP & WTP & WTP & WTP & WTP \\
\hline
\end{tabular}

Sumber: bpk.go.id, 2020.

Penyusunan Laporan Keuangan Pengadilan Agama Lubuklinggau mengacu pada Peraturan Pemerintah Nomor 71 Tahun 2010 tentang Standar Akuntansi Pemerintahan dan kaidahkaidah pengelolaan keuangan yang sehat dalam pemerintahan. Laporan keuangan disajikan dengan basis akrual sehingga akan mampu menyajikan informasi keuangan yang transparan, akurat dan akuntabel. Meskipun dalam 5 (lima) tahun terakhir Pemerintah Kantor Pengadilan Agama Lubuklinggau telah mendapat predikat Wajar Tanpa Pengecualian (WTP) oleh Badan Pemeriksa Keuangan, namun demikian masih terdapat beberapa kekurangan dan kendala yang dihadapi pengguna laporan keuangan, masih dijumpai salah penempatan akun yang menyebabkan akun-akun banyak yang tidak sesuai dengan tempatnya. Penerapan sistem keuangan yang baik pada dasarnya tidak terlepas dari persepsi, wawasan dan profesionalisme dari para pegawai pemerintahan itu sendiri. Terlepas dari kekurangan-kekurangan yang ada tidak ditemukannya penyimpangan-penyimpangan yang signifikan yang dapat mempengaruhi kewajaran dalam penyajian laporan keuangan. Penelitian Nining Asniar Ridzal (2020) menunjukkan bahwa kualitas laporan keuangan berpengaruh positif dan signifikan terhadap akuntabilitas kinerja Badan Pengelolaan Keuangan dan Aset Daerah Kabupaten Buton. Sehingga dalam penelitian ini penulis ingin mengetahui apakah laporan keuangan yang baik itu bisa mempengaruhi akuntabilitas kinerja dalam melakukan pekerjaannya, tujuan penelitian ini yaitu untuk mengetahui pengaruh kualitas laporan keuangan terhadap akuntabilitas kinerja Pengadilan Agama Lubuklinggau. 


\section{Literature Review}

\subsection{Kualitas Laporan Keuangan}

Kualitas laporan keuangan adalah ukuran-ukuran normatif yang perlu diwujudkan dalam informasi akuntansi sehingga dapat memenuhi tujuannya (SAP, 2010:25). Laporan keuangan yang memiliki kualitas yang baik yaitu laporan keuangan yang memenuhi unsur karakteristik dari laporan keuangan, karakteristik laporan keuangan (Mahmudi, 2016: 106) yaitu:

a. Relevan

Laporan keuangan bisa dikatakan relevan apabila informasi yang termuat di dalamnya dapat mempengaruhi keputusan pengguna dengan membantu mereka mengevaluasi peristiwa masa lalu atau masa kini dan memprediksi masa depan serta menegaskan atau mengoreksi hasil evaluasi mereka di masa lalu. informasi laporan keuangan yang relevan dapat dihubungkan dengan maksud penggunanya Informasi.

b. Andal (realiability)

Informasi dalam laporan keuangan bebas dari pengertian yang menyesatkan dan kesalahan material, menyajikan setiap fakta secara jujur, serta dapat diverifikasi

c. Dapat Dibandingkan

Informasi yang termuat dalam laporan keuangan akan lebih berguna jika dapat dibandingkan dengan laporan keuangan periode sebelumnnya atau laporan keuangan entitas pelaporan lain pada umummnya. Perbandingan dapat dilakukan secara internal dan eksternal.

d. Dapat Dipahami

Informasi yang disajikan dalam laporan keuangan dapat dipahami oleh pengguna dan dinyatakan dalam bentuk serta istilah yang disesuaikan dengan batas pemahaman para pengguna. Untuk itu pengguna diasumsikan memiliki pengetahuan yang memadai atas kegiatan dan lingkungan operasi entitas pelaporan, serta adanya kemauan pengguna untuk mempelajari informasi yang dimaksud.

\subsection{Akuntabilitas}

Peraturan Pemerintah Nomor 71 tahun 2010 menjelaskan bahwa akuntabilitas yaitu mempertanggung jawabkan pengelolaan sumber daya serta pelaksanaan kebijakan yang dipercayakan kepada entitas pelaporan dalam mencapai tujuan yang telah ditetapkan secara periodik. Menurut Mahmudi (2016: 18), akuntabilitas publik adalah kewajiban pemegang amanah (agent) untuk memberikan pertanggungjawaban, menyajikan, melaporkan, dan mengungkapkan segala aktivitas dan kegiatan yang menjadi tanggungjawabnya kepada pihak pemberi amanah (principal) yang memiliki hak dan kewenangan untuk memintak pertanggungjawaban tersebut. Dalam melaksanakan akuntabilitas publik, organisasi sektor publik berkewajiban untuk memberikan informasi sebagai bentuk pemenuhan hak-hak publik antara lain: 1) hak untuk tahu (right to know);2) hak untuk diberi informasi (right to be informed); dan 3) hak untuk didengar inspirasinya (right to be heard and to be listened to). Akuntabilitas publik terdiri atas dua macam (Mardiasmo, 2009: 21), yaitu: 1) akuntabilitas vertikal; dan 2) Akuntabilitas horizontal. Akuntabilitas publik yang harus dilakukan oleh organisasi sektor publik, dimensi akuntabilitas yang harus dipenuhi oleh lembaga publik 
antara lain (Hopwood dan Tomkins, 1984, Elwood, 1993), dalam (Mardiasmo 2009: 22): 1) Akuntabilitas Kejujuran dan Hukum; 2) Akuntabilitas Proses; 3) Akuntabilitas Program; dan 4) Akuntabilitas Kebijakan.

\subsection{Kinerja}

Menurut Susan Susanto (2013: 164), kinerja adalah hasil kerja secara kualitas dan kuantitas yang dapat dicapai oleh seorang pegawai dalam melaksanakan tugas sesuai dengan tanggung jawab yang diberikan kepadanya. Menurut Mardiasmo (2009: 122), prestasi pelaksanaan program yang dapat diukur akan mendorong pencapaian prestasi tersebut. Pengukuran prestasi yang dilakukan secara berkelanjutan memberikan umpan baik untuk perbaikan secara terus menerus dan pencapaian tujuan dimasa mendatang, secara umum tujuan sistem pengukuran kinerja adalah: 1) untuk mengkomunikasikan strategi secara lebih baik; 2) untuk mengukur kinerja finansial dan non-finansial secara berimbang sehingga dapat ditelusuri perkembangan pencapaian strategi; 3) untuk mengakomodasikan pemahaman kepentingan manager level menengah bawali serta memotovasi untuk mencapai keselarasan tujuan; dan 4) sebagai alat untuk mencapai kepuasan berdasarkan pendekatan individual dan kemampuan kolektif yang rasional.

Hipotesis Penelitian

$\mathrm{HO}=$ Kualitas laporan keuangan tidak berpengaruh terhadap akuntabilitas kinerja pada Kantor Pengadilan Agama Lubuklinggau

$\mathrm{H} 1$ = Kualitas laporan keuangan berpengaruh terhadap akuntabilitas kinerja pada Kantor Pengadilan Agama Lubuklinggau

\section{Metode Penelitian}

Jenis penelitian yang digunakan didalam penulisan ini adalah peneliti deskriptif. Penelitian yang bertujuan untuk mengetahui nilai masing-masing variabel, baik satu variabel atau lebih sifatnya independen untuk mendapatkan gambaran tentang variabel-variabel tersebut. Data yang digunakan dalam penelitian ini adalah data primer dan data sekunder. Data primer menggunakan kuesioner yang dibagikan kepada responden menggunakan skala likert yaitu: Sangat Setuju $(\mathrm{SS})=5$; Setuju $(\mathrm{S})=4$; $\operatorname{Netral}(\mathrm{N})=3$; Tidak Setuju $(\mathrm{TS})=2$; Sangat Tidak Setuju STS $=1$. Data sekunder berupa analisis dokumen dari laporan keuangan yang telah diaudit oleh Badan Pemeriksaan Keuangan (BPK). Analisis data yang digunakan oleh peneliti adalah analisis kuantitatif. Sampel yang digunakan yaitu seluruh seluruh pegawai Pengadilan Agama Kota Lubuklinggau yang terdiri dari 35 pegawai. Teknik analisis data yang digunakan yaitu untuk mengetahui pengaruh kualitas laporan keuangan terhadap akuntabilitas kinerja pada Kantor Pengadilan Agama Lubuklinggau melalui uji hipotesis. Sebelum melakukan analisis terlebih dahulu dilakukan uji validitas dan uji realibilitas. Adapun persamaan regresi linier yang digunakan adalah:

$$
\mathbf{Y}=\boldsymbol{\alpha}+\boldsymbol{\beta} \mathbf{X}+\mathbf{e}
$$

$\mathrm{Y}=$ Akuntabilitas Kinerja.

$\alpha=$ Harga $Y$ bila $X=0$ (harga kontan). 
$\beta=$ Angka arah atau koefisien regresi.

$\mathrm{X}=$ Kualitas Laporan Keuangan.

$\mathrm{e}=$ error term.

\section{Hasil dan Diskusi}

Penelitian ini bertujuan untuk mengetahui pengaruh kualitas laporan keuangan terhadap akuntabilitas kinerja di Pengadilan Agama Lubuklinggau. Pengumpulan data dilakukan dengan menggunakaan kuesioner yang disampaikan langsung kepada responden. Pengumpulan data pada penelitian ini dilakukan dengan beberapa tahap, yaitu dengan menyebarkan 35 kuesioner kepada responden pada Kantor Pengadilan Agama Lubuklinggau yang seluruh pegawainya dijadikan responden yaitu sebanyak 35 pegawai. Dari 35 kuesioner yang telah disebarkan peneliti sebanyak 35 kuesioner telah kembali dan layak dijadikan data.

\subsection{Karakteristik Responden}

a. Karakteristik Responden Berdasarkan Usia

Tabel 2. Karakteristik Responden Berdasarkan Usia, Tahun 2021

\begin{tabular}{|l|c|c|c|}
\hline No & Usia & Frekuensi & Presentase (\%) \\
\hline 1 & $20-40$ & 21 & $60 \%$ \\
\hline 2 & $41-60$ & 14 & $40 \%$ \\
\hline Jumlah & & 35 & $100 \%$ \\
\hline
\end{tabular}

Sumber : Data primer yang diolah, 2021.

b. Karakteristik Responden Berdasarkan Jenis Kelamin

Tabel 3. Karakteristik Responden Berdasarkan Jenis Kelamin, Tahun 2021

\begin{tabular}{|c|c|c|c|}
\hline No & Jenis Kelamin & Frekuensi & Presentase (\%) \\
\hline 1 & Laki-laki & 20 & $54,3 \%$ \\
\hline 2 & Perempuan & 15 & $45,7 \%$ \\
\hline \multicolumn{2}{|c|}{ Jumlah } & 35 & $100 \%$ \\
\hline
\end{tabular}

Sumber : Data primer yang diolah, 2021.

c. Karakteristik Responden Berdasarkan Pendidikan

Tabel 4. Karakteristik Responden Berdasarkan Pendidikan, Tahun 2021

\begin{tabular}{|c|c|c|c|}
\hline No & Pendidikan & Frekuensi & Presentase (\%) \\
\hline 1 & SLTA & 6 & $17,1 \%$ \\
\hline 3 & D3 & 3 & $8,6 \%$ \\
\hline 3 & S1 & 23 & $65,7 \%$ \\
\hline 4 & S2 & 3 & $8,6 \%$ \\
\hline \multicolumn{2}{|c|}{ Jumlah } & 35 & $100 \%$ \\
\hline
\end{tabular}

Sumber : Data primer yang diolah, 2021. 


\subsection{Gambaran Karakteristik Variabel}

Kuesioner diberikan kepada responden dengan dua variabel, satu variabel bebas (kualitas laporan keuangan) dan satu variabel terikat (akuntabilitas kinerja). Tujuan diberikan kuesioner untuk mengetahui pengaruh dari kualitas laporan keuangan terhadap akuntabilitas kinerja yang ada dikantor Pengadilan Agama Lubuklinggau. Kuesioner diberikan masing-masing variabel berjumlah sepuluh pernyataan. Indikator kualitas laporan keuangan meliputi relevan, andal, dapat dibandingkan dan mudah dipahami. Sedangkan indikator untuk akuntabilitas kinerja meliputi akuntabilitas kejujuran dan hukum, akuntabilitas proses, akuntabilitas program, akuntabilitas kebijakan. Kemudian skor atas jawaban responden dijumlahkan berdasarkan masing-masing dari variabel yang telah diisi oleh responden. Analisis statistik deskriftif untuk mengetahui deskripsi suatu data yang dilihat berdasarkan frekuensi dan persentase dari kedua variabel, dapat dilihat di tabel 5 berikut :

Tabel 5. Descriptive Statistiks

\begin{tabular}{|l|l|l|l|l|l|}
\hline & N & Min & Max & Mean & Std. Deviation \\
\hline Kualitas Laporan & 35 & 33 & 50 & 42,37 & 4,305 \\
Keuangan & 35 & 19 & 30 & 25,20 & 2,530 \\
Akuntabilitas Kinerja & 35 & & & & \\
Valid N (listwise) & 35 & & \\
\hline
\end{tabular}

Sumber : Data primer yang diolah, 2021.

Berdasarkan Tabel 5 menunjukkan bahwa $\mathrm{N}$ atau jumlah data setiap variabel yang valid berjumlah 35, dari 35 data sampel kualitas laporan keuangan (X), nilai minimum sebesar 33, nilai maximum sebesar 50, nilai mean, nilai mean ialah rata sebesar 42,37 , serta nilai standar deviation sebesar 4,305 yang artinya nilai mean lebih besar dari nilai standar deviation sehingga penyimpangan data yang terjadi rendah.

Akuntabilitas kinerja (Y) dari 35 sampel diketahui bahwa nilai minimum sebesar 19, nilai maksimum sebesar 30, nilai mean sebesar 25,20, serta nilai standar deviation sebesar 2,530 yang artinya nilai mean lebih besar dari nilai standar deviation sehingga penyimpangan data yang terjadi rendah.

Standar deviation atau simpangan adalah ukuran penyebaran data. Standar deviation merupakan cerminan dari rata-rata penyimpangan data dari mean. Standar deviation dapat menggambarkan seberapa variasi data, dimana jika nilai standar deviation lebih besar dari nilai mean berarti nilai mean merupakan representasi yang buruk dari keseluruhan data. Namun jika nilai standar deviationnya lebih kecil dari nilai mean berarti nilai mean dapat digunakan sebagai representasi dari keseluruhan data.

\subsection{Hasil Pengelolaan data}

a. Uji Validitas

Validitas didefinisikan sebagai sejauh mana ketepatan dan kecermatan suatu alat ukur dalam melakukan fungsi ukurannya. Pengertian valid tidaknya suatu alat ukur tergantung kemampuan alat tersebut untuk mengukur objek yang diukur dengan cermat dan tepat. Keputusan pada sebuah butir pernyataan dapat dianggap valid. 
Tabel 6. Uji Validitas

\begin{tabular}{|c|c|c|c|c|}
\hline Variabel & Item Pernyataan & Koefisen Korelasi & $\mathrm{r}$ tabel $(n=35)$ & Keterangan \\
\hline \multirow{10}{*}{$\begin{array}{l}\text { Kualitas } \\
\text { Laporan } \\
\text { Keuangan } \\
\text { (X) }\end{array}$} & P1 & 0,540 & 0,334 & Valid \\
\hline & $\mathrm{P} 2$ & 0,772 & 0,334 & Valid \\
\hline & P3 & 0,672 & 0,334 & Valid \\
\hline & $\mathrm{P} 4$ & 0,747 & 0,334 & Valid \\
\hline & P5 & 0,753 & 0,334 & Valid \\
\hline & P6 & 0,775 & 0,334 & Valid \\
\hline & P7 & 0,647 & 0,334 & Valid \\
\hline & P8 & 0,774 & 0,334 & Valid \\
\hline & P9 & 0,747 & 0,334 & Valid \\
\hline & P10 & 0,716 & 0,334 & Valid \\
\hline \multirow{6}{*}{$\begin{array}{l}\text { Akuntabilitas } \\
\text { Kinerja (Y) }\end{array}$} & $\mathrm{P} 1$ & 0,677 & 0,334 & Valid \\
\hline & P2 & 0,676 & 0,334 & Valid \\
\hline & P3 & 0,649 & 0,334 & Valid \\
\hline & P4 & 0,475 & 0,334 & Valid \\
\hline & P5 & 0,744 & 0,334 & Valid \\
\hline & P6 & 0,732 & 0,334 & Valid \\
\hline
\end{tabular}

Sumber : Data primer yang diolah, 2021.

\section{Keterangan:}

\section{KUALITAS LAPORAN KEUANGAN (X1)}

\section{Relevan}

P1 Laporan keuangan yang disusun sesuai dengan SAP, dengan informasi yang lengkap dan diselesaikan secara tepat waktu.

P2

Instansi/lembaga tempat Saya bekerja menyajikan laporan keuangan secara lengkap

\section{Andal}

P3 Transaksi yang disajikan tergambar dengan jujur dan dapat dipertanggungjawabkan sehingga bebas dari Pengertian yang menyesatkan dan dapat diuji kebenarannya

P4 Informasi keuangan yang disajikan dapat dibandingkan dengan laporan keuangan periode sebelumnya. 


\section{Dapat dibandingkan}

P5 Informasi yang disajikan dalam laporan keuangan PA- Lubuklinggau digunakan untuk meningkatkan akuntabilitas kinerja Lubuklinggau digunakan untuk meningkatkan akuntabilitas kinerja

P6 Laporan keuangan yang dihasilkan dapat memberikan informasi untuk mengoreksi ekspektasi mereka dimasa lalu.

P7 Penyajian informasi laporan keuangan telah benar dan memenuhi kebutuhan para pengguna dan tidak berpihak pada kebutuhan tertentu.

\section{Dapat dipahami}

P8 Informasi yang disajikan dalam laporan keuangan menggambarkan dengan jujur transaksi dan peristiwa lainnya sehingga bebas dari pengertian yang menyesatkan dan kesalahan yang bersifat material

P9 Laporan keuangan memberikan informasi untuk pengambilan keputusan saat ini dan mengoreksi keputusan masa lalu atau masa kini

P10 Informasi yang disajikan dalam laporan keuangan telah jelas dan disajikan dalam bentuk serta istilah yang disesuikan dan mudah dipemahaman para pengguna.

AKUNTABILITAS KINERJA (Y)

Akuntabilitas Kejujuran dan Hukum

P1 Akuntabilitas kejujuran di gunakan dalam menyusun laporan keuangan untuk mencapai sasaran kinerja

P2 Laporan keuangan yang di rancang sesuai dengan aturan yang di landaskan hukum guna memberikan hasil kinerja yang baik

\section{Akuntabilitas Proses}

P3 Prosedur yang di gunakan dalam melaksanakan tugas sudah cukup baik dalam hal kecukupan sistem informasi akuntansi, sistem informasi manajemen dan prosedur administrasi

\section{Akuntabilitas Program}

P4 Program-program laporan keuangan di rancang dengan mempertimbangkan prinsip efesiensi dan efektifitas untuk menghasilkan kinerja yang Maksimal untuk mencapai target atau kepentingan publik

P5 Pelaksanaan program-program penyusunan anggaran benar-benar di rasakan manfaatnya untuk meningkatkan kinerja

\section{Akuntabilitas Kebijakan}

P6 Kebijakan atau aturan yang di buat oleh pemerintah berguana dalam mengevaluasi kinerja

Nilai patokan untuk uji validitas adalah koefisien korelasi (Corrected Item-Total Correlation) yang mendapat nilai lebih besar dari 0,3. Berdasarkan hasil uji validitas pada tabel 6, diketahui seluruh pernyataan bersifat valid. Alternatif ketentuan validitas suatu pernyataan pada kuesioner juga dapat dibandingkan dengan nilai rtabel. Untuk menentukan nilai rtabel terlebih dahulu dihitung nilai derajat bebas (degree of freedom) dengan rumus $n-2$, di mana menyatakan banyaknya responden untuk uji validitas. 
Diketahui jumlah responden yang dilibatkan untuk uji validitas kuesioner sebanyakn $n=35$, sehingga derajat bebas bernilai $n-2=35-2=33$. Nilai rtabel dengan derajat bebas 33 adalah rtabel $=0,334$. Nilai patokan untuk uji validitas adalah koefisien korelasi (Corrected ItemTotal Correlation) yang mendapat nilai lebih besar dari rtabel $=0,334$. Berdasarkan hasil uji validitas pada tabel 6 diketahui seluruh pernyataan bersifat valid.

\section{b. Uji Reabilitas}

Reabilitas pada dasarnya adalah sejauh mana hasil suatu pengukuran dapat dipercaya. Jika hasil pengukuran yang dilakukan berulang menghasilkan hasil yang relatif sama, pengukuran tersebut dianggap memiliki tingkat reliabilitas yang baik. Untuk mengukur konsisten pengaruh tidaknya variabel $\mathrm{X}$ dengan variabel $\mathrm{Y}$, sebelum dilakukan nya pengujian reabilitas harus ada dasar pengambilan keputusan yaitu alpha sebesar 0,70. Variabel yang dianggap reliabel jika nilai variabel tersebut lebih besar dari $>0,70$ jika lebih kecil maka variabel yang diteliti tidak bisa dikatakan reliabel karena $<0,70$. Hasil dari pengujian reliabilitas pada variabel penelitian ini sebagai berikut :

Tabel 7. Uji Reabilitas

\begin{tabular}{|c|c|c|c|c|}
\hline Variabel & $\begin{array}{c}\text { Cronbach's } \\
\text { Alpha }\end{array}$ & $\begin{array}{c}\text { N of } \\
\text { Items }\end{array}$ & r tabel & status \\
\hline Kualitas Laporan Keuangan (X) & 0,891 & 10 & 0,7 & Valid \\
\hline Akuntabilitas Kinerja (Y) & 0,734 & 6 & 0,7 & Valid \\
\hline
\end{tabular}

Sumber : Data primer yang diolah, 2021.

Berdasarkan hasil uji reabilitas pada Tabel 7 nilai cronbach's alpha untuk kualitas laporan keuangan sebesar 0,891 lebih besar dari nilai dasar alpha 0,7 maka dapat dikatakan kualitas laporan keuangan memberikan tingkat reliabel yang sangat kuat. Begitu juga dengan akuntabilitas kinerja yang mempunyai nilai cronbach alpha 0,734 sama dengan nilai dasar alpha 0,7 maka dapat diatakan memiliki hungungan kuat karena mempunyai tingkat reliable yang tinggi sesuai dengan teori dari Sugiyono (2017: 130), Jika nilai alpha Cronbach sama dengan nilai dasar alpha 0,7 atau lebih besar dari nilai dasar alpha maka dikatakan item tersebut memberikan tingkat reliabel yang cukup tinggi, namun sebaliknya apabila nilai alpha Cronbach dibawah nilai dasar alpha 0,7 maka dikatakan item tersebut kurang reliabel. Uji reliabilitas dipakai untuk membuktikan konsistensi suatu alat ukur. Sebuah alat ukur dikatakan reliabel apabila dalam beberapa kali pengukuran terhadap kelompok atau subyek yang sama diperoleh hasil yang relatif sama.

\section{c. Uji Regresi Linear Sederhana}

Metode regresi linier sederhana ini dimaksudkan untuk mengetahui seberapa besar tingkat pengaruh antara kualitas laporan keuangan dengan akuntabilitas kinerja. Untuk itu penulis sajikan hasil uji regresi linier sederhana berdasarkan Tabel 8 berikut: 
Tabel 8. Coefficients ${ }^{\mathrm{a}}$ Uji Regresi Linear Sederhana

\begin{tabular}{|c|c|c|c|c|c|}
\hline \multirow[b]{2}{*}{ Model } & \multicolumn{2}{|c|}{$\begin{array}{l}\text { Unstandardized } \\
\text { Coefficients }\end{array}$} & \multirow{2}{*}{\begin{tabular}{|c|}
$\begin{array}{l}\text { Standardized } \\
\text { Coefficients }\end{array}$ \\
Beta \\
\end{tabular}} & & \multirow[b]{2}{*}{ Sig. } \\
\hline & $\mathrm{B}$ & Std. Error & & & \\
\hline 1 (Constant) & 3,643 & 2,142 & & 1,701 & \\
\hline Laporan Keuangan & ,509 & 050 & ,870 & 10,126 & \\
\hline
\end{tabular}

a. Dependent Variable: Akuntabilitas Kinerja,

Sumber : Data primer yang diolah, 2021.

Pada output ini, dikemukakan nilai koefisien dari persamaan regresi. Model persamaan regresi sederhana digunakan adalah :

$$
\mathrm{Y}=3,643+0,509 \mathrm{X}
$$

Berdasarkan Tabel 8 disajikan kembali nilai koefisien regresi untuk variabel bebas. Untuk Variabel kualitas laporan keuangan 0,509 (bernilai positif), artinya jika ada peningkatan kualitas laporan keuangan (X) sebesar 100\%, maka akan meningkatkan akuntabilitas kinerja instansi pemerintah (Y) sebesar 50,9\%, begitu juga sebaliknya jika ada penurunan kualitas laporan keuangan (X) sebesar 100\%, maka akan menurunkan akuntabilitas kinerja instansi pemerintah (Y) sebesar 50,9\%. Berarti kualitas laporan keuangan berpengaruh terhadap akuntabilitas kinerja yang semakin baik berdampak positif terhadap akuntabilitas kinerja pemerintah.

\section{d. Analisis Deskriftip Variabel Penelitian}

Pengaruh Kualitas Laporan Keuangan Terhadap Akuntabiitas Kinerja Pada Kantor Pengadilan Agama Lubuklinggau dengan menggunakan tabelarasi dengan kuesioner yang diterima sebanyak 35 responden, yaitu sebagai berikut:

\section{1) Variabel Kualitas Laporan Keuangan (X)}

Kualitas Laporan Keuangan diukur dengan 10 pernyataan, adapun hasil analisis deskriptifnya dapat dilihat sebagai berikut :

a) Relevan

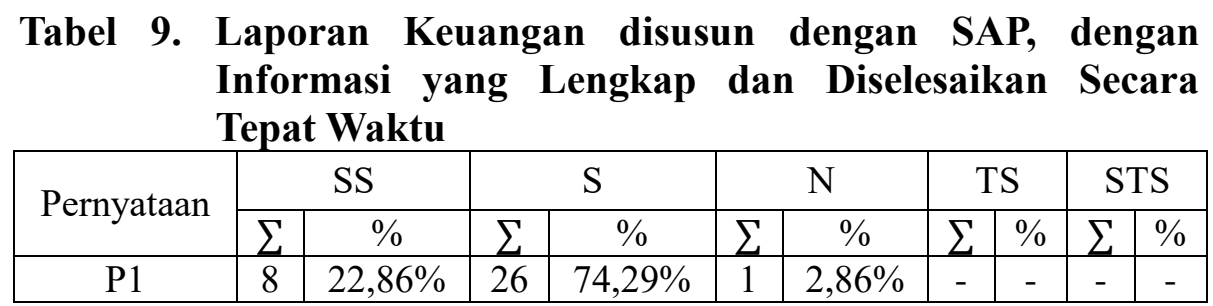

Sumber : Data primer yang diolah, 2021.

Berdasarkan Tabel 9 hasil jawaban sebanyak 8 atau 22,86\% responden menyatakan Sangat Setuju dengan pernyataan tersebut karena beralasan laporan keuangan harus sesuai SAP dan 
diselesaikan dengan batas waktu yang telah ditentukan, sebanyak 26 atau 74,29\% reponden menyatakan Setuju, dan sebanyak 1 atau 2,86\% responden menyatakan jawaban Netral serta tidak satupun responden menjawab tidak setuju ataupun sangat tidak setuju.

\section{Tabel 10. Instansi Ditempat Saya Bekera Menyaikan Laporan Keuangan Secara Lengkap}

\begin{tabular}{|c|c|c|c|c|c|c|c|c|c|c|}
\hline \multirow{2}{*}{ Pernyataan } & \multicolumn{2}{|c|}{ SS } & \multicolumn{2}{|c|}{ S } & \multicolumn{2}{|c|}{ N } & \multicolumn{2}{|c|}{ TS } & \multicolumn{2}{c|}{ STS } \\
\cline { 2 - 10 } & $\sum$ & $\%$ & $\sum$ & $\%$ & $\sum$ & $\%$ & $\sum$ & $\%$ & $\sum$ & $\%$ \\
\hline P2 & 8 & $22,86 \%$ & 24 & $68,57 \%$ & 3 & $8,57 \%$ & - & - & - & - \\
\hline
\end{tabular}

Sumber : Data primer yang diolah, 2021.

Berdasarkan Tabel 10 diketahui sebanyak 8 atau 22,86\% responden menawab sangat setuju dengan pernyataan tersesebut, 24 atau $68,57 \%$ responden yang menawab setuju, dan sebanyak 3 atau $8,57 \%$ responden menyatakan netral. Dari pernyataan tersebut menunjukan bahwan Instansi keuangan di Pengadilan Agama Kota Lubuklinggau sangat profesional dalam mengelola dan menyajikan informasi. Terlihat dari responden tidak satupun yang menjawab tidak setuju maupun sangat tidak setuju.

b) Andal

Tabel 11. Transaksi Yang Disajikan Tergambar dengan Jujur dan dapat Dipertanggungjawabkan sehingga Bebas dari Pengertian yang Menyesatkan dan dapat Diuji Kebenarannya

\begin{tabular}{|c|c|c|c|c|c|c|c|c|c|c|}
\hline \multirow{2}{*}{ Pernyataan } & \multicolumn{2}{|c|}{ SS } & \multicolumn{2}{|c|}{ S } & \multicolumn{2}{|c|}{ N } & \multicolumn{2}{|c|}{ TS } & \multicolumn{2}{|c|}{ STS } \\
\cline { 2 - 10 } & $\sum$ & $\%$ & $\sum$ & $\%$ & $\sum$ & $\%$ & $\sum$ & $\%$ & $\sum$ & $\%$ \\
\hline P3 & 9 & $25,71 \%$ & 22 & $62,86 \%$ & 4 & $11,43 \%$ & - & - & - & - \\
\hline
\end{tabular}

Sumber : Data primer yang diolah, 2021.

Berdasarkan Tabel 11 tentang pernyataan diketahui, sebanyak 9 atau 25,71\% responden menjawab sangat setuju, 22 atau $62,86 \%$ responden menjawab setuju. Dari pernyataan ini dapat menunjukkan bahwa transaksi yang telah dibuat tergambar sangat bagus terbukti dari $100 \%$ responden hanya 4 atau $11,43 \%$ responden menjawab netral serta tidak satupun responden menjawab tidak setuju ataupun sangat tidak setuju.

Tabel 12. Informasi Keuangan Yang Disajikan Dapat Dibandingkan Dengan Laporan Keuangan Periode Sebelumnya.

\begin{tabular}{|c|c|c|c|c|c|c|c|c|c|c|}
\hline \multirow{2}{*}{ Pernyataan } & \multicolumn{2}{|c|}{ SS } & \multicolumn{2}{|c|}{ S } & \multicolumn{2}{c|}{ N } & \multicolumn{2}{|c|}{ TS } & \multicolumn{2}{|c|}{ STS } \\
\cline { 2 - 10 } & $\sum$ & $\%$ & $\sum$ & $\%$ & $\sum$ & $\%$ & $\sum$ & $\%$ & $\sum$ & $\%$ \\
\hline P4 & 12 & $34,29 \%$ & 22 & $62,86 \%$ & 1 & $2,86 \%$ & - & - & - & - \\
\hline
\end{tabular}

Sumber : Data primer yang diolah, 2021.

Berdasarkan Tabel 12 tentang pernyataan diketahui,, sebanyak 12 atau 34,29\% menyatakan sngat setuju dengan pernyataan tersebut, 22 atau $62,86 \%$ setuju dengan pernyataan tersebut, hal ini menunjukkan bahwa laporan keuangan dapat menjadi pembanding utuk periode sebelumnya. Dan hanya 1 atau 2,86\% yang menjawab netral serta tidak ada satupun 
responden yang menjawab tidak setuju ataupun sangat tidak setuju.

c) Dapat Dibandingkan

\begin{tabular}{|c|c|c|c|c|c|c|c|c|c|c|}
\hline \multirow{3}{*}{ Pernyataan } & & \multirow{2}{*}{\multicolumn{2}{|c|}{$\mathrm{S}$}} & \multirow{2}{*}{\multicolumn{2}{|c|}{$\mathrm{N}$}} & \multirow{2}{*}{\multicolumn{2}{|c|}{ TS }} & \multirow{2}{*}{\multicolumn{2}{|c|}{ STS }} \\
\hline & & & & & & & & & & \\
\hline & $\sum$ & $\%$ & $\sum$ & $\%$ & $\sum$ & $\%$ & $\sum$ & $\%$ & $\sum$ & $\%$ \\
\hline P5 & 10 & $28,57 \%$ & 22 & $62,86 \%$ & 3 & $8,57 \%$ & - & - & - & - \\
\hline
\end{tabular}

Sumber : Data primer yang diolah, tahun 2021.

Berdasarkan Tabel 13 tentang pernyataan diketahui,, sebanyak 10 atau 28,57\% responden menjawab sangat setuju dan 22 atau $62,86 \%$ responden menyatakan sangat setuju. Sehingga hal ini menunjukkan bahwa penyajian laporan keuangan di Kantor Pengadilan Agama Lubuklinggau mampu meningkatkan akuntabilitas kinerja. 3 atau 8,57\% responden menjawab netral. Dan tidak satu pun responden menjawab tidak setuju atau sangat tidak setuju dengan pernyataaan tersebut.

Tabel 14. Laporan Keuangan Yang Dihasilkan Dapat Memberikan Informasi Untuk Mengoreksi Ekspektasi Mereka Dimasa Lalu.

\begin{tabular}{|c|c|c|c|c|c|c|c|c|c|c|}
\hline \multirow{2}{*}{ Pernyataan } & \multicolumn{2}{|c|}{ SS } & \multicolumn{2}{|c|}{ S } & \multicolumn{2}{|c|}{ N } & \multicolumn{2}{|c|}{ TS } & \multicolumn{2}{|c|}{ STS } \\
\cline { 2 - 10 } & $\sum$ & $\%$ & $\sum$ & $\%$ & $\sum$ & $\%$ & $\sum$ & $\%$ & $\sum$ & $\%$ \\
\hline P6 & 16 & $45,71 \%$ & 15 & $42,86 \%$ & 4 & $11,43 \%$ & - & - & - & - \\
\hline
\end{tabular}

Sumber : Data primer yang diolah, 2021.

Berdasarkan Tabel 14 tentang pernyataan diketahui, sebanyak 16 atau 45,71\% responden menjawab sangat setuju dengan alasan sebagai bahan pertimbangan dapat memaksimalkan lagi usaha dimasa depan dan yang belum terealisasikan dimasa lalu dapat di realisasikan dimasa yang akan datang. Sebanyak 15 atau 42,86\% menyatakan setuju dengan alasan bahwan laporan keuangan dimasa lalu bisa memberikan informasi yang bisa diandalkan dimasa yang akan datang, 4 atau 11,43\% menyatakan netral dengan alasan bahwa tidak semua laporan keuangan dimasa lalu bisa memberika informasi dimasa yang akan datang. Dan tidaksatu pun responden menjawab tidak setuju atau sangat tidak setuju dengan pernyataaan tersebut.

Tabel 15. Penyajian Informasi Laporan Keuangan Telah Benar Dan Memenuhi Kebutuhan Para Pengguna dan Tidak Berpihak Pada Kebutuhan Tertentu.

\begin{tabular}{|c|c|c|c|c|c|c|c|c|c|c|}
\hline \multirow{2}{*}{ Pernyataan } & \multicolumn{2}{|c|}{ SS } & \multicolumn{2}{|c|}{ S } & \multicolumn{2}{|c|}{ N } & \multicolumn{2}{|c|}{ TS } & \multicolumn{2}{|c|}{ STS } \\
\cline { 2 - 10 } & $\sum$ & $\%$ & $\sum$ & $\%$ & $\sum$ & $\%$ & $\sum$ & $\%$ & $\sum$ & $\%$ \\
\hline P7 & 13 & $37,14 \%$ & 15 & $42,86 \%$ & 7 & $20 \%$ & - & - & - & - \\
\hline
\end{tabular}

Sumber : Data primer yang diolah, 2021. 
Berdasarkan tabel 15 tentang pernyataan diketahui,, Sebanyak 13 atau 37,14\% responden menjawab sangat setuju dengan beralasan bahwa laporan keuangan telah benar dan akan dipublish untuk umum bukan hanya pihak tertentu saja. Sebanyak 15 atau 42,86\% menjawab setuju dengan beralasan laporan keuangan harus disajikan untuk umum untuk mengetahui dan menilai kinerja pemerintahan. Dan sebanyak 7 atau 20\% menjawab netral serta tidaksatu pun responden menjawab tidak setuju atau sangat tidak setuju dengan pernyataaan tersebut.

d) Dapat Dipahami

Tabel 16. Informasi Yang Disajikan Dalam Laporan

Keuangan Menggambarkan Dengan Jujur

Transaksi Dan Peristiwa Lainnya Sehingga

Bebas Dari Pengertian Yang Menyesatkan dan

Kesalahan Yang Bersifat Material

\begin{tabular}{|c|c|c|c|c|c|c|c|c|c|c|}
\hline \multirow{2}{*}{ Pernyataan } & \multicolumn{2}{|r|}{ SS } & \multicolumn{2}{|c|}{$\mathrm{S}$} & \multicolumn{2}{|r|}{$\mathrm{N}$} & \multicolumn{2}{|c|}{ TS } & \multicolumn{2}{|c|}{ STS } \\
\hline & $\sum$ & $\%$ & $\sum$ & $\%$ & $\sum$ & $\%$ & $\sum$ & $\%$ & $\sum$ & $\%$ \\
\hline P7 & 17 & $48,57 \%$ & 14 & $40 \%$ & 4 & $11,43 \%$ & - & - & - & - \\
\hline
\end{tabular}

Sumber : Data primer yang diolah, 2021.

Berdasarkan Tabel 16 tentang pernyataan diketahui, sebanyak 17 atau 48,57\% responden menyatakan sangat setuju dengan alasan jika laporan keuangan yang disajikan menggambarkan peristiwa yang sedang terjadi maka dapat dipastikan laporan keuangan tersebut berkualitas. Sebanyak 14 atau 40\%. 4 responden menjawab setuju dengan alasan jika laporan yang telah tersaji berkualitas sehingga bebas dari pengertian yang menyesatkan.sebanyak 4 atau atau $11,43 \%$ responden menjawab netral serta tidaksatu pun responden menjawab tidak setuju atau sangat tidak setuju dengan pernyataaan tersebut.

Tabel 17. Laporan Keuangan Memberikan Informasi Untuk Pengambilan Keputusan Saat Ini dan Mengoreksi Keputusan Masa Lalu Atau Masa Kini

\begin{tabular}{|c|c|c|c|c|c|c|c|c|c|c|}
\hline \multirow{2}{*}{ Pernyataan } & \multicolumn{2}{|c|}{ SS } & \multicolumn{2}{|c|}{ S } & \multicolumn{2}{|c|}{ N } & \multicolumn{2}{|c|}{ TS } & \multicolumn{2}{c|}{ STS } \\
\cline { 2 - 11 } & $\sum$ & $\%$ & $\sum$ & $\%$ & $\sum$ & $\%$ & $\sum$ & $\%$ & $\sum$ & $\%$ \\
\hline P9 & 12 & $34,29 \%$ & 22 & $62,86 \%$ & 1 & $2,86 \%$ & - & - & - & - \\
\hline
\end{tabular}

Sumber : Data primer yang diolah, 2021.

Berdasarkan Tabel 17 tentang pernyataan diketahui, sebanyak 12 atau 34,29\% responden menjawab sangat setuju dengan alasan sangat setuju jika informasi yang ada di laporan keuangan yang dihasilkan berguna dalam pengambilan keputusan yang benar. sebanyak 22 atau $62,86 \%$ responden menjawab setuju dengan beralasan agar informasi yang terkandung didalam laporan keuangan dapat mengkoreksi dan berguna di dalam pengambilan keputusan. Sebanyak 1 atau 2,86\% responden menjawab netral serta tidaksatu pun responden menjawab tidak setuju atau sangat tidak setuju dengan pernyataaan tersebut. 


\section{Tabel 18. Informasi Yang Disajikan Dalam Laporan Keuangan Telah Jelas Dan Disajikan Dalam Bentuk Serta Istilah Yang Disesuikan dan Mudah Dipemahaman Para Pengguna.}

\begin{tabular}{|c|c|c|c|c|c|c|c|c|c|c|}
\hline \multirow{2}{*}{ Pernyataan } & \multicolumn{2}{|c|}{ SS } & \multicolumn{2}{|c|}{ S } & \multicolumn{2}{|c|}{ N } & \multicolumn{2}{|c|}{ TS } & \multicolumn{2}{c|}{ STS } \\
\cline { 2 - 10 } & $\sum$ & $\%$ & $\sum$ & $\%$ & $\sum$ & $\%$ & $\sum$ & $\%$ & $\sum$ & $\%$ \\
\hline P10 & 10 & $28,57 \%$ & 21 & $60 \%$ & 4 & $11,43 \%$ & - & - & - & - \\
\hline
\end{tabular}

Sumber : Data primer yang diolah, 2021.

Berdasarkan Tabel 18 tentang pernyataan diketahui,, sebanyak 10 atau 28,57\% menjawab sangat setuju dengan beralasan agar laporan keuangan yang telah tersaji dapat mudah dipahami dan dimengerti agar supaya disaat pengambilan keputusan tidak terjadi kesalahan. Sebanyak 21 atau $60 \%$ responden menjawab setuju dengan beralasan agar informasi yang terkandung didalam laporan keuangan bisa dan mudah dipahami oleh masyarakat dan bukan hanya pihak-pihak yang berkepentingan saja. Dan sebanyak 4 atau 11,43\% responden menjawab netral serta tidaksatu pun responden menjawab tidak setuju atau sangat tidak setuju dengan pernyataaan tersebut.

\section{2) Variabel Akuntabilitas Kinerja (Y)}

Variabel akuntabilitas kinerja ini diukur dengan 6 pernyataan. Adapun analisis deskriptip hasil jawaban responden dapat dilihat sebagai berikut :

a) Akuntabilitas Kejujuran dan Hukum

Tabel 19. Akuntabilitas Kejujuran di Gunakan Dalam Menyusun Laporan Keuangan Untuk Mencapai Sasaran Kinerja

\begin{tabular}{|c|c|c|c|c|c|c|c|c|c|c|}
\hline \multirow{2}{*}{ Pernyataan } & \multicolumn{2}{|c|}{ SS } & \multicolumn{2}{|c|}{ S } & \multicolumn{2}{|c|}{ N } & \multicolumn{2}{|c|}{ TS } & \multicolumn{2}{|c|}{ STS } \\
\cline { 2 - 11 } & $\sum$ & $\%$ & $\sum$ & $\%$ & $\sum$ & $\%$ & $\sum$ & $\%$ & $\sum$ & $\%$ \\
\hline P1 & 9 & $25.71 \%$ & 22 & $62,86 \%$ & 4 & $11,43 \%$ & - & - & - & - \\
\hline
\end{tabular}

Sumber : Data primer yang diolah, 2021.

Berdasarkan Tabel 19 hasil jawaban, sebanyak 9 atau 25.71\% responden menjawab sangat setuju dengan alasan akuntabilitas kejujuran digunakan dalam mencapai sasaran kinerja. Sebanyak 22 atau $62,86 \%$ responden menjawab setuju dengan alasan bahwa akuntabilitas sangat diperlukan dalam menyusun laporan keuangan dalam mencapai sasaran kinerja. Sebanyak 4 atau $11,43 \%$ responden menjawab netral, serta tidaksatu pun responden menjawab tidak setuju atau sangat tidak setuju dengan pernyataaan tersebut.

Tabel 20. Laporan Keuangan Yang Di Rancang Sesuai Dengan Aturan Yang di Landaskan Hukum Guna Memberikan Hasil Kinerja Yang Baik.

\begin{tabular}{|c|c|c|c|c|c|c|c|c|c|c|}
\hline \multirow{2}{*}{ Pernyataan } & \multicolumn{2}{|c|}{ SS } & \multicolumn{2}{|c|}{ S } & \multicolumn{2}{|c|}{ N } & \multicolumn{2}{|c|}{ TS } & \multicolumn{2}{|c|}{ STS } \\
\cline { 2 - 10 } & $\sum$ & $\%$ & $\sum$ & $\%$ & $\sum$ & $\%$ & $\sum$ & $\%$ & $\sum$ & $\%$ \\
\hline P2 & 12 & $34,29 \%$ & 22 & $62,86 \%$ & 1 & $2,86 \%$ & - & - & - & - \\
\hline
\end{tabular}

Sumber : Data primer yang diolah, 2021. 
Berdasarkan Tabel 20 hasil jawaban, sebanyak 12 atau 34,29\% responden menjawab sangat setuju dengan alasan agar laporan keuangan yang telah disusun tidak terjadi kesalahan san dapat memenuhi sasaran kinerja yang telah diinginkan. Sebanyak 22 atau 62,86\% responden menjawab setuju dengan alasan laporan keuangan harus dirancang dengan landasan hukum yang baik agar memberikan hasil yang maksimal. Sebanyak 1 atau 2,86\% responden menjawab netral serta tidak satu pun responden menjawab tidak setuju atau sangat tidak setuju dengan pernyataaan tersebut.

b) Akuntabilitas proses

Tabel 21. Prosedur Yang Di Gunakan Dalam Melaksanakan Tugas Sudah Cukup Baik Dalam Hal Kecukupan Sistem Informasi Akuntansi, Sistem Informasi Manajemen Dan Prosedur Administrasi

\begin{tabular}{|c|c|c|c|c|c|c|c|c|c|c|}
\hline \multirow{2}{*}{ Pernyataan } & \multicolumn{2}{|c|}{ SS } & \multicolumn{2}{|c|}{ S } & \multicolumn{2}{|c|}{ N } & \multicolumn{2}{|c|}{ TS } & \multicolumn{2}{|c|}{ STS } \\
\cline { 2 - 11 } & $\sum$ & $\%$ & $\sum$ & $\%$ & $\sum$ & $\%$ & $\sum$ & $\%$ & $\sum$ & $\%$ \\
\hline P3 & 10 & $28,57 \%$ & 22 & $62,86 \%$ & 3 & $8,57 \%$ & - & - & - & - \\
\hline
\end{tabular}

Sumber : Data primer yang diolah, 2021.

Berdasarkan Tabel 21 hasil jawaban, sebanyak 10 atau 28,57\% responden sangat setuju dengan alasan pelaksanaan tugas akan lebih baik jika didukung dengan sistem yang baik juga sehingga dapat memudahkan pekerjaan. Sebanyak 22 atau 62,86\% responden menyatakan setuju dengan alasan tugas akan lebih baik jika didukung dengan sistem yang baik juga. Sebanyak 3 atau 8,57\% responden menjawab netral serta tidaksatu pun responden menjawab tidak setuju atau sangat tidak setuju dengan pernyataaan tersebut.

c) Akuntabilitas Program

Tabel 22. Program-program laporan keuangan di rancang dengan mempertimbangkan prinsip efesiensi dan efektifitas untukmenghasilkan kinerja yang maksimal sehingga mencapai target atau kepentingan publik

\begin{tabular}{|c|c|c|c|c|c|c|c|c|c|c|}
\hline \multirow{2}{*}{ Pernyataan } & \multicolumn{2}{|c|}{ SS } & \multicolumn{2}{c|}{ S } & \multicolumn{2}{|c|}{ N } & \multicolumn{2}{c|}{ TS } & \multicolumn{2}{c|}{ STS } \\
\cline { 2 - 11 } & $\sum$ & $\%$ & $\sum$ & $\%$ & $\sum$ & $\%$ & $\sum$ & $\%$ & $\sum$ & $\%$ \\
\hline P4 & 8 & $22,86 \%$ & 19 & $54,29 \%$ & 8 & $22,86 \%$ & - & - & - & - \\
\hline
\end{tabular}

Sumber : Data primer yang diolah, 2021.

Berdasarkan Tabel 22 hasil jawaban, sebanyak 8 atau 22,86\% responden menjawab sangat setuju dan 19 atau 54,29\% responden menjwab setuju dengan alasan program laporan keuangan yang dirancang dengan menggunakan prinsip efesiensi pasti akan menghasilkan laporan keuangan yang efesien juga. Sebanyak 8 atau 22,86\% responden menjawab netral serta tidaksatu pun responden menjawab tidak setuju atau sangat tidak setuju dengan pernyataaan tersebut. 
Tabel 23. Pelaksanaan program-program penyusunan anggaran benar-benar di rasakan manfaatnya untuk meningkatkan kinerja

\begin{tabular}{|c|c|c|c|c|c|c|c|c|c|c|}
\hline \multirow{2}{*}{ Pernyataan } & \multicolumn{2}{|c|}{ SS } & \multicolumn{2}{|c|}{ S } & \multicolumn{2}{|c|}{ N } & \multicolumn{2}{|c|}{ TS } & \multicolumn{2}{|c|}{ STS } \\
\cline { 2 - 11 } & $\sum$ & $\%$ & $\sum$ & $\%$ & $\sum$ & $\%$ & $\sum$ & $\%$ & $\sum$ & $\%$ \\
\hline P5 & 13 & $37,14 \%$ & 15 & $42,86 \%$ & 7 & $20 \%$ & - & - & - & - \\
\hline
\end{tabular}

Sumber : Data primer yang diolah, 2021.

Berdasarkan Tabel 23 hasil jawaban, sebanyak 13 atau 37,14\% responden menjawab sangat setuju dan sebanyak 15 atau 42,86\% responden menjawab setuju dengan beralasan bahwa seluruh program penyusunaan anggaran dapat meningkatkan kinerja sehingga bisa mencapai target yang telah di rencanakan. 7 atau $20 \%$ responden menjawab netral serta tidaksatu pun responden menjawab tidak setuju atau sangat tidak setuju dengan pernyataaan tersebut.

d) Akuntabilitas Kebijakan

Tabel 24. Kebijakan atau Aturan Yang di Buat oleh Pemerintah Berguana dalam Mengevaluasi Kinerja

\begin{tabular}{|c|c|c|c|c|c|c|c|c|c|c|}
\hline \multirow{2}{*}{ Pernyataan } & \multicolumn{2}{|c|}{ SS } & \multicolumn{2}{|c|}{ S } & \multicolumn{2}{|c|}{ N } & \multicolumn{2}{|c|}{ TS } & \multicolumn{2}{|c|}{ STS } \\
\cline { 2 - 11 } & $\sum$ & $\%$ & $\sum$ & $\%$ & $\sum$ & $\%$ & $\sum$ & $\%$ & $\sum$ & $\%$ \\
\hline P6 & 17 & $48,57 \%$ & 14 & $40 \%$ & 4 & $11,43 \%$ & - & - & - & - \\
\hline
\end{tabular}

Sumber : Data primer yang diolah, 2021.

Berdasarkan Tabel 24 hasil jawaban, sebanyak 17 atau 48,57\% responden menjawab sangat setuju dengan alasan jika program kebijakan dari pemerintah berguna dalam membantu mengevaluasi guna meningkatkan kinerja. sebanyak 14 atau $40 \%$ responden menjawab setuju dengan alasan apabilah laporan keuangan disusun dengan baik maka sasaran yang akan dicapai baik pula. 4 atau 11,43\% responden menjawab netral serta tidaksatu pun responden menjawab tidak setuju atau sangat tidak setuju dengan pernyataaan tersebut.

Berdasarkan uraian akuntabilitas kinerja diatas dapat disimpulkan bahwa kinerja pemerintah memiliki indikator tersendiri dalam menghasilkan laporan keuangan yang berkualitas. Terlaksana atau tidaknya program dari pemerintah menjadi tolak ukur berhasil atau tidaknya pemerintah dalam mencapai akuntabilitas kinerja.

\subsection{Uji Hipotesis}

a. Uji $R^{2}$

Koefisien determinasi (R square) bertujuan untuk mengetahui seberapa besar kemampuan variabel independen kualitas laporan keuangan mampu menjelaskan variabel dependen (akuntabilitas kinerja). Berikut ini hasil uji determinasi ( $R$ Square).

Tabel 25. Uji Determinasi

\begin{tabular}{|c|c|c|c|c|}
\hline Model & $\mathrm{R}$ & $\mathrm{R}$ Square & $\begin{array}{c}\text { Adjusted R } \\
\text { Square }\end{array}$ & $\begin{array}{c}\text { Std. Error of } \\
\text { the Estimate }\end{array}$ \\
\hline 1 &, $870^{\mathrm{a}}$ &, 757 &, 749 & 1,263 \\
\hline
\end{tabular}

a. Predictors: (Constant), $X$

Sumber : Data primer yang diolah, 2021. 
Berdasarkan kepada Tabel 25 diketahui nilai $R$ square sebesar 0,757 atau (75,7\%), Ini menunjukkan bahwa dengan menggunakan model regresi yang didapatkan dimana variabel independen yaitu kualitas laporan keuangan memiliki pengaruh terhadap variabel akuntabilitas kinerja sebesar 75,7\%, hal ini membuktikan bahwa pengaruh kualitas laporan keuangan terhadap akuntabilitas kinerja sesuai dengan interval koefisien yaitu 0,60-0,799 yang masuk dalam kategori kuat. Sedangkan sisanya $24,3 \%$ dijelaskan dengan faktor atau variabel lain yang tidak diketahui dan tidak termasuk dalam analisis regresi ini.

Kualitas laporan keuangan dapat menunjukkan apakah pemerintah pemerintahan tersebut telah melakukan pengelolaan keuangan dengan baik atau tidaknya, dengan melihat kualitas laporan keuangan akan membantu melihat dan membantu mengontrol pelaksanaan kegiatankegiatan pemerintah baik dalam proses perencanaan, pelaksanaan, maupun pertanggungjawaban dalam mencapai keberhasilan yang telah direncanakan dan meningkatkan lagi kinerja pemerintah tersebut.

b) Uji-t

Tabel 26. Uji t Coefficients ${ }^{\mathrm{a}}$

\begin{tabular}{|c|c|c|c|c|c|}
\hline \multirow[b]{2}{*}{ Model } & \multicolumn{2}{|c|}{$\begin{array}{l}\text { Unstandardized } \\
\text { Coefficients }\end{array}$} & $\begin{array}{l}\text { Standardized } \\
\text { Coefficients }\end{array}$ & \multirow[b]{2}{*}{$\mathrm{t}$} & \multirow[b]{2}{*}{ Sig. } \\
\hline & $\mathrm{B}$ & Std. Error & Beta & & \\
\hline $\begin{array}{ll}1 & \text { (Constant) } \\
& \text { Laporan Keuangan }\end{array}$ & $\begin{array}{l}3,643 \\
, 509\end{array}$ & $\begin{array}{l}2,142 \\
, 050\end{array}$ &, 870 & $\begin{array}{l}1,701 \\
10,126\end{array}$ & $\begin{array}{l}, 098 \\
, 000\end{array}$ \\
\hline
\end{tabular}

a. Dependent Variable: Akuntabilitas Kinerja

Sumber : Data primer yang diolah, 2021.

Pada Tabel 26, $t_{\text {hitung }}$ pada kualitas laporan keuangan adalah 10,126. Pada derajat bebas (df) $=\mathrm{N}-2=35-2=33$, maka ditemukan $t_{\text {tabel }}$ sebesar 1,674. Maka dapat ditarik kesimpulan bahwa $t_{\text {hitung }}>t_{\text {tabel }}(10,126>1,701)$. Kriteria dalam akuntabilitas kinerja adalah nilai

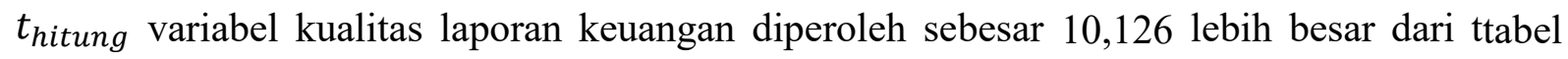
1.701 dengan tingkat signifikansi sebesar $0.000<0.05$, maka hipotesis yang diajukan diterima. Hal ini berarti bahwa kualitas laporan keuangan berpengaruh signifikan terhadap Akuntabilitas Kinerja Pemerintah pada taraf signifikan $\alpha=5 \%$.

Dari hasil perhitungan uji $\mathrm{t}$ bahwa dapat disimpulkan terdapat pengaruh antara kualitas laporan keuangan dan akuntabilitas kinerja, hal ini dikarenakan bahwa nilai signifikansi kualitas laporan keuangan lebih kecil dari 0,05 sehingga hasil yang diperoleh signifikan. Penelitian ini sejalan dengna penelitian sebelumnya yang dilakukan oleh Nining Asniar Ridzal pada tahun (2020) menunjukkan bahwa kualitas laporan keuangan berpengaruh positif dan signifikan terhadap akuntabilitas kinerja Badan Pengelolaan Keuangan dan Aset Daerah Kabupaten Buton. Hal ini berarti bahwa baik tidaknya akuntabilitas kinerja dari suatu instansi pemerintah sangat dipengaruhi oleh kualitas laporan keuangan yang dihasilkan. Jika akuntabilitas kinerja instansi pemerintah menyajikan laporan keuangan sesuai standar akuntansi pemerintahan maka laporan keuangan yang dihasilkan akan berkualitas.

Kantor Pengadilan Agama Lubuklinggau telah memiliki sistem pencatatan keuangan yang 
baik meskipun masih terdapat kekurangan didalam pembuatan laporannya seperti, masih dijumpai ketidak mampuan dalam menyajikan pos-pos laporan keuangan dengan tepat, dan Catatan atas Laporan Keuangan (CaLK) yang kurang lengkap dan informative akan tetapi dibalik kekurang-kekurangan tersebut tidak ditemukannya penyimpangan-penyimpangan yang signifikan yang mempengaruhi kewajaran dalam penyajian laporan keuangan. Hal ini terbukti dengan jawaban dari responden terhadap variabel kualitas laporan keuangan yang memiliki rata-rata statistik deskriprif 42,37 lebih besar dibandingkan dengan standar deviation yang hanya bernilai 4,305 . Hal ini juga ditunjukan oleh pernyataan mengenai informasi yang disajikan dalam laporan keuangan menggambarkan dengan jujur transaksi dan peristiwa lainnya sehingga bebas dari Pengertian yang menyesatkan dan kesalahan yang bersifat material, yang diketahui sebanyak 17 responden atau 48,6\% menjawab sangat setuju dengan alasan laporan keuangan yang berkualitas harus disajikan secara jujur dan mudah dipahami oleh pengguna dengan menggunkan bahas yang baik dan benar sesuai dengan standar akuntansi pemerintah. Hal lain ditunjukkan juga dengan adanya pengawasan langsung dari BPK dalam melaksanakan tugas dan tanggungjawabnya dalam mengevauasi kinerja dimasa yang akan datang.

Pelaksanaan akuntabilitas haruslah sejalan dengan peraturan perundang-undangan agar pengelolaan keuangan dapat menjadi lebih baik. Setiap kegiatan yang hasilnya berhubungan dengan Negara harus dapat dipertanggungjawabkan kepada seluruh masyarat sebagai pemegang kedaulatan tertinggi Negara sesuai dengan ketentuan peraturan perundangundangan yang berlaku.

Secara keseluruhan pengelolaan keuangan dalam kantor Pengadilan Agama Lubuklinggau sudah baik. Hal ini ditunjukkan oleh nilai rata-rata statistik deskriprif 25,20 lebih besar dibandingkan dengan standar deviation hanya bernilai 2,530 yang diperoleh dari jawaban responden berdasarkan tingkat kesetujuan terhadap pernyataan yang berhubungan dengan akuntabilitas. Hal ini juga ditunjukan oleh pernyataan mengenai Kebijakan atau aturan yang dibuat oleh pemerintah berguna dalam mengevaluasi kinerja, diketahui sebanyak 17 responden atau 48,6\% menjawab sangat setuju dengan alasan kebijakan yang ditetapkan oleh pemerintah bisa membuat para pegawai bisa lebih teratur dan tertata dalam meningkatan kinerjanya guna mencapai tujuan yang telah di organisasi.

\section{Kesimpulan}

Kualitas Laporan Keuangan yang baik berpengaruh signifikan terhadap akuntabilitas kinerja pada kantor pengadilan agama. Hal ini ditunjukkan dengan uji-t, Nilai $t_{\text {hitung variabel }}$ kualitas laporan keuangan diperoleh sebesar 15,517 lebih besar dari ttabel 1.692 dengan tingkat signifikansi sebesar $0.000<0.05$, maka hipotesis yang diajukan diterima. Hal ini berarti bahwa kualitas laporan keuangan berpengaruh signifikan terhadap Akuntabilitas Kinerja Pemerintah pada taraf signifikan $\alpha=5 \%$.

Berdasarkan uji R square didapatkan nilai sebesar 0,749 atau (74,9\%), Ini menunjukkan bahwa dengan menggunakan model regresi yang didapatkan dimana variabel independen yaitu kualitas laporan keuangan memiliki pengaruh terhadap variabel akuntabilitas kinerja sebesar 74,9\%, hal ini membuktikan bahwa pengaruh kualitas laporan keuangan terhadap akuntabilitas kinerja sesuai dengan interval koefisien yaitu 0,60 - 0,799 yang masuk dalam kategori kuat. 


\section{References}

Abdul Halim. 2007. Akuntansi Sektor Publik Akuntansi keuangan daerah, Edisi Revisi, Jakarta: Salemba Empat.

Abdul Halim, 2015. Dasar-Dasar Audit Laporan Keuangan. Yogyakarta: Sekolah Tinggi Ilmu Manajemen YKPN.

Deddi Nordiawan dan Ayuningtyas Hertianti. 2010. Akuntansi Sektor Publik. Edisi 2. Jakarta: Salemba Empat.

Fauzi, F., Dencik, A. B., \& Asiati, D. I. (2019). Metodologi Penelitian untuk manajemen dan akuntansi. Jakarta: Salemba Empat.

Indra Bastian. 2006. Akuntansi Sektor Publik: Suatu Pengantar. Jakarta: Erlangga.

Indra Bastian. 2010. Akuntansi Sektor Publik: Suatu Pengantar. Edisi 3. Jakarta: Erlangga.

Instruksi Presiden Nomor 7 Tahun 1999 tentang Akuntabilitas Kinerja Instansi Pemerintah.

Keputusan Kepala LAN No.239/IX/6/8/2003 tentang Pedoman Penyusunan Pendapatan Akuntabilitas Kinerja Instansi Pemerintah.

Mahmudi. 2007. Manajemen Kinerja Sektor Publik. Yogyakarta: Unit Penerbit dan Percetakan Sekolah Tinggi Ilmu Manajemen YKPN.

Mahmudi. 2010. Manajemen Kinerja Sektor Publik. Yogyakarta: Sekolah Tinggi Ilmu Manajemen YKPN.

Mahmudi, 2016. Akuntansi Sektor Publik. Yogyakarta: UII Press Yogyakarta.

Mardiasmo, 2009. Akuntansi Sektor Publik. Yogyakarta.

Moh. Mahsun, dkk 2013. Akuntansi Sektor Publik. Yogyakarta: Fakultas Ekonomika dan Bisnis UGM.

Muindro Renyowijoyo. 2013. Akuntansi Sektor Publik: Organisasi Non Laba. Edisi Ketiga, Jakarta: Mitra Wacana Media

Nining Asniar Ridzal. 2020. Pengaruh Kualitas Laporan Keuangan Terhadap Akuntabilitas Kinerja Pada Badan Pengelolaan Keuangan dan Aset Daerah (BPKAD) Kabupaten Buton. Financial: Jurnal Akuntansi, Vol 6, No 1, https://financial.ac.id/index.php/financial/article/view/135

Nurlan Darise. 2008. Akuntansi Keuangan Daerah.Jakarta: Indeks.

Peraturan Menteri Keuangan Nomor 177/PMK.05/2015 tentang Pedoman Penyusunan Laporan Keuangan Kementerian Negara/Lembaga.

Sugiyono, 2016. Metode Penelitian. Bandung: Alfabeta.

Sugiyono. 2011. Metode Penelitian Kuantitatif kualitatif dan R\&D. Bandung: Alfabeta

Undang-Undang Nomor 14 Tahun 2015 tentang Anggaran Pendapatan dan Belanja Negara.

Undang-Undang Republik Indonesia Nomor 17 Tahun 2003 Tentang Keuangan Negara.

http://www.pa-lubuklinggau.go.id/images/calk/CALK_SMT_II_2017_005-01-

Published by: 
compressed.pdf. diakses 10 Desember 2020.

https://jdih.kemenkeu.go.id/fulltext/2003/17tahun2003uu.htm. diakses 14 Desember 2020.

https://peraturan.bpk.go.id./Home/Details/5095/pp-no-71-tahun-2010. diakses 14 Desember 2020.

\section{Copyrights}

Copyright for this article is retained by the author(s), with first publication rights granted to the journal.

This is an open-access article distributed under the terms and conditions of the Creative Commons Attribution license (http://creativecommons.org/licenses/by/4.0/) 